\title{
TANGGUNG JAWAB PERUSAHAAN DALAM PERUSAHAAN KELOMPOK MENURUT SISTEM HUKUM PERUSAHAAN INDONESIA
}

\author{
Budi Sutrisno \\ Fakultas Hukum Universitas Mataram \\ Lombok, NTB, Indonesia \\ Email: sutrisnobudi@gmail.com
}

\begin{abstract}
Abstrak
Penelitian ini bertujuan untuk mengkaji dan penganalisis terkait tanggungjawab dalam perusahaan kelompok menurut sistem hukum perusahaan indonesia dan hubungan hukum antara perusahaan induk dengan anak perusahaan dalam perusahaan kelompok terhadap utang yang dimiliki anak perusahaan. Metode yang digunakan dalam penelitian ini adalah metode normatif dengan mengunakan pendekatan peraturan perundang-undangan dan pendekatan konseptual.Hasil kajian dan pembahasan dapat disimpulkan bahwaSecara yuridis induk perusahaan tidak bertanggung jawab secara pribadi atas perikatan yang dilakukan anak perusahaannya, demikian juga tidak bertanggung jawab atas kerugian masing-masing perusahaan melebihi saham yang dimilikinya, namun jika hutang-hutang anak-anak perusahaan itu disebabkan terpenuhinya keadaan-keadaan yang ditentukan dalam pasal 3 ayat 2 UUPT maka induk perusahaan bisa dimintakan tanggung jawabnya secara pribadi, tidak hanya sebatas nilai nominal saham yang dimilikinya pada anak perusahaan tersebut.
\end{abstract}

\section{Kata Kunci : Tanggung Jawab; Perusahaa Kelompok; Saham.}

\begin{abstract}
This study aims to examine and analyze related responsibilities in a group company according to the Indonesian corporate legal system and the legal relationship between the parent company and its subsidiaries in the group company against debt owned by the subsidiary. The method used in this study is a normative method using the statutory approach and conceptual approach. The results of the study and discussion can be concluded that the juridical parent company is not personally responsible for the commitments carried out by its subsidiaries, as well as not responsible for the loss of each - each company exceeds its shares, but if the debts of the subsidiaries are due to the fulfillment of the conditions specified in Article 3 paragraph 2 of the Company Law, the holding company can be held personally liable, not only limited to the nominal value of shares owned by the children the company.
\end{abstract}

Keywords: Responsibility; Group Companies; Stocks.

\section{A. PENDAHULUAN}

Perkembangan hukum korporasi saat ini sudah sedemikian pesat, yang hingga dalam praktek bisa ditemui perusahaaan-perusahaan berskala besar yang tidak lagi dijalankan melalui bentuk perusahaan tunggal, melainkan dalam bentuk perusahaan group. Berbagai bentuk perusahaan group di Indonesia dapat kita temui seperti Perusahaan Group Semen Gresik, Group Astra, Group Bakrie, Group Bhakrie, Group Mnc dan lain sebagainya. ${ }^{1}$ Contoh perusahaan kelompok yang lainnya di Indonesia juga bisa disebutkan seperti berikut ini yaitu PT Pupuk Indonesia Holding Company, PT Semen Indonesia (Persero) Tbk, PT Medco Energi Internasional Tbk,

${ }^{1}$ Sulistiowati.(2010). Aspek Hukum dan Realitas Bisnis Perusahaan Grup di Indonesia. Jakarta: Erlangga, hlm. 3 
PT Indonesia Aluminium (Inalum), PT Bumi Resources Tbk, Maspion group, Salim Group dan lain-lain.

Dalam ranah hukum eksistensi perusahaan kelompok menjadi suatu polemik tersendiri. Selain karena tidak ada pengaturan secara khusus terkait dengan perusahaan kelompok, maka keberadaan perusahaan kelompok sering kali dihubungkan dengantanggung jawab hukum antara induk perusahaan (holding company) dan anak perusahaan yang berada ranah yang tidak jelas karena ketiadaan aturan hukumnya dan berbagai masalah lainnya.

Apabila dicermati, di Indonesia, walaupun pengaturan tentang perusahaan kelompok tidak diatur secara langsung di dalam undang-undang. Namun bisa ditafsirkan dari ketentuanketentuanyang terkandung dalam Undang-undang Perseroan Terbatas No. 40 Tahun 2007 tentang Perseroan Terbatas. Keberadaan holding company di Indonesia bukan merupakan hal baru. Perusahaan kelompok merupakan kebutuhan dari masyarakat bisnis Indonesia yang semakin berkembang.Dengan adanya konsep Group Companymaka diharapkan suatu perusahaan dapat membangun suatu bisnisdenganlebih cepat dan efisien.Berdasarkanlatarbelakangtersebut maka diatrik isu hukkum bagaimanahubungan hukum antara Induk Perusahaan dengananak perusahaandalamPerusahaanKelompok dan bagaimanatanggung jawabindukperusahaan terhadaphutang-hutang yang dimilikianakperusahaandalamperusahaankelompok.

\section{B. METODE PENELITIAN}

Metode penelitian yang digunakan dalam tulisan ini adalah penelitian hukum normatif, dengan menggunakan pendekatan peraturan perundang-undangan dan pendektan konseptual, dengan bahan hukum primer literatur hukum dan undang-undang, sedangkan bahan hukum tersier seperti istilah melalui kamus hukum/ensiklopedia hukum.

\section{PEMBAHASAN}

Seperti dijelaskan oleh Raaijamakers bahwa kerja sama di antara perusahaan-perusahaan yang dikenal dengan nama konsern (consern) atau group company atau perusahaan kelompok, secara umum dapat diberi pengertian sebagai suatu susunan dari perusahaan-perusahaan yang secara yuridis tetap mandiri dan yang satu dengan yang lain merupakan satu kesatuan ekonomi yang dipimpin oleh suatu perusahaan induk ${ }^{2}$.Konsern atau perusahaan kelompok (group company) dapat terjadi dalam suatu susunan baik secara vertikal maupun horisontal.

Berdasarkan pada pengertian pengertian di atas maka dalam concern mengandung unsurunsur pokok yaitu adanya kesatuan dari sudut ekonomi, dan ada jumlah banyak dari segi yuridis karena kemandirian dari masing-masing perusahaan yang tergabung dalam kelompok perusahaan tersebut. Walaupun dalam perusahaan kelompok bisa saja dalam bentuk badan usaha tidak berbadan hukum seperti CV atau Firma namun fenomena yang terlihat adalah bahwa yang tergabung dalam perusahaan kelompok dalam hubungan concern adalah dalam bentuk badan usaha berbadan hukum seperti Perseroan Terbatas.

Hubungan-hubungan konsern dapat diartikan sebagai hubungan antara badan-badan hukum, misalnya badan hukum dengan bentuk perseroan, seperti PT. Hubungan itu terjadi jjka pimpinan kegiatan ekonomi dari dua atau lebih perusahaan dikoordinasikan sedemikian rupa sehingga antara sesama perusahaan itu banyak atau sedikit terdapat susunan yang erat dalam aspek ekonomi, keuangan dan organisasi, Dengan kata singkat dapat dikemukakan bahwa perusahaan perusahaan itu berada di bawah pimpinan sentral atau pengurusan bersama atau dapat juga dikatakan bahwa mereka secara uniform atau seragam ${ }^{3}$.

\footnotetext{
${ }^{2}$ Raaijmakers.(1976). Joint venture. Kluwer Deventer, hlm. 80.

${ }^{3}$ Honee.(1981). Concernrecht en medezeggenschaps regelingen. Kluwer Deventer, hlm. 1
} 
Hukum konsern dengan susunan dan hubungan-hubungan perusahaan-perusahaan yang ada di dalamnya merupakan bagian dari hukum persekutuan perniagaan khususnya hukum perseroan, Akan tetapi, hukum konsern mempunyai kekhususan tersendiri dari hukum perseroan karena hukum konsern menangani gejala khusus yaitu: tersusunnya perusahaanperusahaan yang secara yuridis mandiri dalam suatu susunan yang erat antara satu sama lain sehingga dari sudut ekonomi dipandang sebagai satu kesatuan yang berada di bawah satu pimpinan. Sebagaimana telah dikemukakan di muka bahwa hukum konsern mengenal istilahistilah tersendiri, Dalam kaitannya satu sama lain perusahaan-perusahaan yang membentuk susunan kesatuan itu dilihat sebagai perusahaan induk dan perusahaan anak dan sebagai satu kesatuan ekonomi atau keseluruhan disebutkan sebagai konsern atau perusahaan kelompok atau Group Company.

Raiijmakers mengemukakan bahwa hukum konsern dapat dilihat dari dua sisi berlainan yaitu dari sisi ekstern dan intern. Hukum konsern ekstern menyangkuł semua ketentuan yang bertujuan mengatur kepentingankepentingan yang bersifat hubungan keluar misalnya kepentingan pemegang sahan diluar (out side shareholders), kreditur dan buruh. Hukum konsern intern menyangkut semua ketentuan yang ada kaitannya dengan struktur intern dałam konsern sebagai suatu keseluruhan dan khususnya juga mengenai kemungkinan melaksanakan pimpinan konsern dałam hubungan konsern dan mengenai struktur pimpinan sentrai dari konsern itu sendiri ${ }^{4}$. Hukum Konsem intern ini adalah menyangkut sisi ke dałam dan konsern. Sebagai contoh yaitu tentang pertanggungjawaban menurut hukum dari pengurus perusahaan induk dan perusahaan anak mengenai pemenuhan tugas yang seharusnya dilakukan; mengenai sejauh mana kewenangan perusahaan induk memberi petunjuk atau pengarahan atau perintah terhadap perusahaan anak; mengenai kewenangan dalam pembangunan intem konsern oleh pimpinan sentral dan mengenai pengaruh pimpinan sentral dalam pembangunan perusahaanperusahaan yang tergabung di dalam konsern.

Di dalam konsern terdapat hubungan antara perusahaan-perusahaan sedemikian rupa yang tidak hanya berdasarkan pemilikan saham melainkan juga atas dasar hak bersuara secara yuridis dan nyata dari satu perusahaan atas perusahaan Iainnya. Hal ini menyangkut baik pemilikan mayoritas saham Oleh perusahaan induk di dalam perusahaan anak dan dengan demikian memiliki hak bersuara dalam Rapat Umum Pemegang Saham (RUPS) dari perusahaan anak. Lebih lanjut sebagai konsekuensi dari pemilikan saham mayoritas oleh perusahaan induk pada anak perusahaan maka adalah logis jika timbul pula kekuasaan yuridis dan nyata dari perusahaan induk untuk mengangkat dan memberhentikan pengurus atau komisaris perusahaan anak.

Dari identifikasi penulis, berkaitan dengan hubungan-hubungan hukum concern antara induk perusahaan dan anak perusahaan dalam perusahaan kelompok sendiri dapat terlihat dari beberapa aspek, yaitu: ${ }^{5}$

1. Kepemilikan Induk Perusahaan atas Saham Anak Perusahaan.

Kepemilikan induk atas saham anak perusahaan dalam jumlah signifikan memberikan kewenangan kepada induk perusahaan untuk bertindak sebagai pimpinan sentral yang mengendalikan anak-anak perusahaan sebagai kesatuan manajemen. Kepemilikan saham pada anak perusahaan memberikan hak suara kepada induk perusahaan untuk mengendalikan anak perusahaan melalui berbagai mekanisme pengendalian yang ada, seperti rapat umum pemegang saham.

\footnotetext{
${ }^{4}$ Raaijmakers, Op.cit, hlm. 87

${ }^{5}$ Sulistiowati, Op.cit, hlm. 96
} 
2. Rapat Umum Pemegang Saham (RUPS).

Induk perusahan memiliki kewenangan untuk mengendalikan anak perusahan melalui mekanisme RUPS anak perusahaan. Dalam RUPS anak perusahaan, induk perusahaan dapat menetapkan hal-hal strategis yang dapat mendukung pencapaian tujuan perusahaan kelompok sebagai kesatuan ekonomi.

3. Penempatan Anggota Direksi dan/atau Dewan Komisaris Anak Perusahaan.

4. Melalui kepemilikan atas saham anak perusahaan, induk perusahaan memiliki kewenangan untuk menempatkan anggota direksi dan/atau dewan komisaris induk perusahaan untuk merangkap menjadi direksi atau komisaris anak perusahaan.

5. Keterkaitan melalui Perjanjian Hak Suara.

Keterkaitanindukdananakperusahaanjugadapatterjadikarenaperjanjianhakbersuara yang dilakukan antara pemegang saham pendiri, yang menyepakati bahwa penunjukan direksi dan dewan komisaris ditentukan oleh salah satu pemegang saham pendiri.

6. Keterkaitan melalui Kontrak

Perseroan dapat menyerahkan kendali atas manajemen kepada perseroan lain melalui Perjanjian Pengelolaan Perusahaan. Sedangkan didalam penjelasan Pasal 29 UndangUndang No.1 Tahun $1995^{6}$ anak perusahaan adalah perseroan yang mempunyai hubungan khusus dengan perseroan lainnya yang dapat terjadi karena: ${ }^{7}$

a) Lebih dari 50\% sahamnya dimiliki induk perusahaan (holding company);

b) Lebih dari 50\% suara dalam RUPS, dikuasai oleh induk perusahaannya;

c) Kontrolatasjalannya perseroan, pengangkatan danpemberhentian direksi dankomisaris sangat dipengaruhi oleh induk perusahaan.

Selanjutnya secara yuridis yaitu dengan mengkaitkan dalam ketentuan Undang-undang No. 40 Tahun 2007 tentang Perseroan Terbatas, diuraikan mengenai bentuk hubungan yang membentuk hubungan-hubungan concern atau perusahaan kelompok atau grup company itu secara berurutan.

Didalam praktek suatu hubungan kerjasama dalam bidang usaha diupayakan sesuai kepentingan yang bersangkutan, sehingga ada bentuk-bentuk tersendiri yang dapat menuju pada terjadinya hubungan-hubungan konsern antara perusahaan induk dengan anak perusahaannya dalam bentuk hubungan yaitu:

\section{1) Penggabungan/merger/fusi}

Pengertianfusi(penggabungan)ditujukankepadapenggabunganperusahaan-perusahaan, sehingga dari sudut ekonomi mereka merupakan suatu kesatuan. Di dalam praktek menurut Raaymaker $^{8}$ perusahaan yang berfusi ke dalam perusahaan lain jarang menjadi lebur dan diikuti dengan likuidasi dari badan hukumnya. Perusahaan yang bergabung atau berfusi itu masih tetap dibiarkan aktifdan secara organisatoris disesuaikanke dalamkeseluruhankesatuan ekonomi dari perusahaan yang menerima penggabungan perusahaan itu. Di dalam pasal 1 angka8Undang-UndangNo40tahun2007 tentangPerseroanTerbataspenggabungandiartikan sebagai perbuatan hukum yang dilakukan oleh satu Perseroan atau lebih untuk menggabungkan diri dengan Perseroan lain yang telah ada yang mengakibatkan aktiva dan pasiva dari Perseroan yang menggabungkan diri beralih karena hukum kepada Perseroan yang menerima

${ }^{6}$ Didalam UU No 40 Tahun 2007 tentang perseroan Terbatas khususnya penjelasan pasal 36 tidak ada penjelasan seperti yang dikemukakan dalam UU no 1 Tahun 1995

${ }^{7}$ Ibid., hlm. 97

${ }^{8}$ Raaymaker.(1976). Joint Venture. Kluwer Deventer, hlm. 80 
penggabungan dan selanjutnya status badan hukum Perseroan yang menggabungkan diri berakhir karena hukum.

\section{2) Pengambil alihan atau akuisisi}

Bentuk hubungan dalam kelompok perusahaan yang lain dikenal dengan nama pengambil alihan atau akuisisiatau overname atau pengambilalihan. Dalam pengambilalihan perusahaan yang lebih besar karena pemilikan saham lebih besar dan penunjukan anggota di dalam dewan pengurus dan dewankomisaris dirasakan sebagaimenguasai ataumendominasi. Didalamkerja sama itu tidak terdapat sifat timbal balik. Hal di atas sesuai dengan pengertian ditentukan dalam Pasal 1 angka 11 UUPT yang menentukan bahwa yang dimaksud dengan Pengambil alihan adalah perbuatan hukum yang dilakukan oleh badan hukum atau orang perseorangan untuk mengambil alih saham Perseroan yang mengakibatkan beralihnya pengendalian atas Perseroantersebut. Contoh-contoh perusahaandi Indonesia yang melakukan perbuatan akuisisi adalah PT Danone yang melakukan akuisisi atas PT Aqua Golden Mississipi, PT Bank Rakyat Indonesia (Persero) Tbk yang mengakuisisi PT Bank Agroniaga Tbk. Dalam pengambil alihan atau akuisisi pengendalian atas perseroan tersebut terlihat bahwa perusahaan yang lebih besar karena pemilihan saham lebih besar dan penunjukan anggota di dałam dewan pengurus dan dewan komisaris, dirasakan sebagai menguasai atau mendominasi. Di dalam kerja sama juga tidak terdapat sifat timbal balik.

\section{3) Pendirian Anak Perusahaan/pemisahan perusahaan}

Bentuk hubungan hukum antara induk perusahaan dengan anak perusahaandalamhubungan concern dalam perusahaankelompokdapat terjadi juga melalui pendirian anak perusahaan yang berarti juga terjadi adanya pememecahan atau pemisahan perusahaan.Fenomena yang terlihat dapat terjadi bahwa suatu perusahaanmemecahkan diri menjadi satuan-satuan yang lebih kecil dan perusahaan-perusahaan ini menjadi perusahaan anak yangberada di bawah naungan atau perlindungan sebuah perusahaan induk atau dalam keadaan ini dikenal dengan sebutan holding company untuk melaksanakan usahanya. Alasan alasan yang menyebabkan pemecahan perusahaan ini juga dapat terletak pada kemungkinan untuk mengatasi atau membagi risiko. Konstruksi perusahaan induk dan anak (holding company and daughter company) dapat meringankan masalah-masalah yang dihadapi oleh suatu perusahaan yang sudah tua. Dalam hal itu masalah suksesi juga dapat menjadi alasan pemecahan perusahaan. Pendirian suatu perusahaan baru yang saham-sahamnya dipegang oleh perusahaan yang tua merupakan suatu jalan keluar dari suatu kesulitan, sebab perusahaan baru itulah yang akan melaksanakan kegiatan usaha seperti transaksi dagang, persediaanpersediaan, pemasukkan tagihan-tagihan dan hutang-hutang ${ }^{9}$.Contoh contoh perusahaanperusahaan yang mendirikan anak-anak perusahaan sehingga terbentuk holding company, group company atau perusahaan kelompok, Seperti Group Bakrie yang memiliki berbagai macam usaha seperti di bidang property, pertambangan, metal hingga mass media, Group PT Djarum, Group PT Indofood Sukses Makmur dan juga Sampoerna Group. Selain itu juga PT Telkom Indeonesia, BUMN yang mendirikan anak perusahaan bernama PT TELIN yang lebih banyak beroperasi secara internasional.

Secara normatifpengertian pendirian anak perusahaan/pemisahan perusahaan ditentukan dalam pasal 1 angka 12 UUPT yang menentukan bahwa pemisahan adalahperbuatan hukum yang dilakukan oleh Perseroan untuk memisahkan usaha yang mengakibatkan seluruh aktiva dan pasiva Perseroan beralih karena hukum kepada 2 (dua) Perseroan atau lebih atau

\footnotetext{
${ }^{9}$ Bartman, Op.cit, hlm. 24
} 
sebagian aktiva dan pasiva Perseroan beralih karena hukum kepada 1 (satu)Perseroan atau lebih.

Pemisahan dapat dilakukan dengan cara pemisahan murni dan pemisahan tidak murni, yang dimana pemisahan murni mengakibatkan seluruh aktiva dan pasiva Perseroan beralih karena hukum kepada 2(dua) Perseroan lain atau lebih yang menerima peralihan dan Perseroan yang melakukan pemisahan usaha tersebut berakhir karena hukum, sedangkan pemisahan tidak murni mengakibatkan sebagianaktivadanpasivaPerseroanberalihkarenahukumkepada1(satu)Perseroanlain ataulebihyangmenerimaperalihan,danPerseroanyangmelakukanPemisahantersebuttetap ada.

\section{4) Joint Venture}

Istilah joint venture merupakan salah satu bentuk kerja sama yang sangat dikenal di dalam dunia bisnis atau usaha. Walaupun secara konsep joint venture adalah merupakan suatu bentuk kerja sama yang tidak mempermasalahkan dari mana subyek yang melakukan kerjasama namun istilah ini sering digunakan ketika ada kerjasama dalam bisnis antara pemodal asing dengan pemodal dalamnegeri.MenurutErman Rajagukguk bahwajoint venture agreementadalah "suatu bentuk kerjasama antara pemilik modal nasional dengan modal asing yang didasari pada suatu kontraktual (perjanjian) ${ }^{10}$.Sedangkan Peter Mahmud mengatakan bahwa kontrakjoint venture adalah "suatu kontrak atau perjanjuan antara dua perusahaan guna mendirikan suatu perusahaan baru. Perusahaan baru inilah yang kemudian disebut sebagai perusahaan joint venture ${ }^{11}$.Contoh-contoh joint venture yang terjadi di Indonesia adalah antara lain : joint venture antara PT Indofood Sukses Makmur Tbk dengan Nestle S.A Switzerland dalam penetrasi pasar di industri consumer goods, X1 Axiata dan Indosat Ooredoo membuat perusahaan patungan PT One Indonesia Sinergy dalam memperluas jaringan telepon seluler, PT Newmont Nusa Tenggara yang merupakan joint venture antara Newmont Ltd, Sumitomo Corporation dan PT Pukuafu yang melakukan bidang usahanya penambangan emas di Pulau Sumbawa Nusa Tenggara Barat.

Dari banyaknya faktor yang harus dipikirkan sebelum terjadinya suatu kerja sama yang berbentuk joint venture, maka kedua belah pihak harus membicarakan semua secara baik, sehingga kehendak bekerja sama itu terwujud. Ideal sekali jika semuanya itu disepakati lebih dulu, dan selanjutnya pendirian atau terjadinya bentuk joint venture itu diadakan dengan suatu perjanjian secara tegas.

Untuk itu maka dalam suatu joint venture terbentuk di antara beberapa perusahaan harus ada perjanjian tegas di antara mereka. Arti pentingnya dibuat suatu perjanjian pada pembentukan joint venture dapat dilihat dari beberapa fungsi perjanjian itu terhadap pihak yang bekerja sama, yaitu:

a) Bisa berfungsi sebagai peraturan mengenai hubungan hukum antara sesama pihak. Hal ini menyangkut pengaturan tentang batas-batas bidang kerja sama dan bidang yang masih tetap merupakan kewenangan masing-masing pihak.

b) Berfungsi sebagai peraturan mengenai hubungan hukum di antara para pihak (baik bersama-sama maupun sendiri) di satu pihak, dan perusahaan joint venture di pihak lain. Menjadi dasar untuk melaksanakan pimpinan yang dibutuhkan untuk kepentingan bersama di dalam kerja sama itu sedangan politik perusahaan yang akan ditempuh hanyalah dapat dipandang sah apabila untuk itu terdapat kesepakatan bersama di dalam suatu perjanjian yang sebelumnya telah ada.

\footnotetext{
${ }^{10}$ Erman Rajagukguk, et al.(1995). Hukum Investasi. Jakarta: UI, hlm. 350

${ }^{11}$ Peter Mahmud dalam Salim HS, Budi Sutrisno.(2008). Hukum Investasi di Indonesia. Bandung: Rajawali Pers, hlm. 206
} 
c) Berfungsi sebagai dasar peraturan yang memungkinkan pihak-pihak secara individual mempunyai hak melakukan perbuatan tertentu, tidak tergantung atau terpisah dari joint venture.

Dengan demikian dapat disimpulkan, bahwa keberadaan perjanjian atau pengaturan mengenai kerja sama adalah merupakan hal yang pokok atau esensial untuk adanya joint venture. Jika tidak ada perjanjian maka dapat mempengaruhi posisi dari sesama pemegang saham karena tidak terdapat pedoman yang pasti berdasarkan kesepakatan yang dapat dipaksakan sehubungan dengan garis pimpinan yana hams diikuti masing-masing sebagai kebersamaan dan perusahaan bersama.

Selanjutnya dari aspek adanya hubungan concern dalam joint venture seperti dalam perusahaan kelompok dapat ditunjukkan dengan posisi-posisi dominan dalam penyertaan modal dan penempatan pelaksana joint vebture dari pihak yang mendominasi yang bisa mengendalikan kerja sama itu. Para pihak yang ada dalam joint venture agreement, menentukan syarat syarat untuk membuat joint venture company dengan status perseroan, syarat-syarat tersebut mengatur mengenai definisi definisi dari suatu istilah yang digunakan, para pihak, segi permodalan (sero), peran para pihak, nama, tempat dan jangka waktu berdirinya perusahaan, serta klausa-klausa lain sehingga perusahaan yang diharapkan dapat terbentuk. Pembentukan perseroan terbatas sebagai sebuah badan hukum tunduk pada hukum perusahaan (company law), yaitu Undang-undang Nomor 40 Tahun 2007 Tentang Perseroan terbatas.

Joint Venture Agreement yang dibuat oleh investor asing dan investor nasional akhirnya bermuara pada pendirian Joint Venture Company, sehingga joint venture company dapat dikatakan berdiri atau lahir atas dasar perjanjian. Asas kebebasan berkontrak (freedom of contract) dalam hukum perjanjian, memungkinkan hal itu terjadi, sepanjang tidak melanggar ketentuan hukum, kepatutan dan kesusilaan yang baik. Tidak hanya itu, asas Pacta Sun Servanda juga menjadi dasar dari perjanjian tersebut dimanasebuah perjanjian yang dibuat secarah sah, berlaku sebagai undang-undang bagi mereka yang membuatnya (pasal 1338 ayat 1 KUHPerdata) serta memiliki kekuatan mengikat terhadap para pihak yang membuatnya.

Dari sudut kegiatan ekonomi perusahaan dalam grup merupakan satu kesatuan, namun dari segi yuridis masing-masing perusahaan anggota grup tersebut mempunyai karakteristik tersendiri, yaitu bahwa masing-masing perusahaan yang bergabung dalam perusahaan grup adalah merupakan badan hukum-badan hukum yang berdiri sendiri.

Apabila salah satu anak perusahaan melakukan perikatan dengan pihak ketiga maka keterikatan secara yuridis dari induk perusahaan yang muncul hanya selaku pemegang saham, tanggung jawabnya terhadap pelunasan hutang tersebut hanya sebatas dan sebesar nilai nominal saham yang dimilikinya di perseroan terbatas dari anak perusahaannya itu, tidak meliputi harta pribadi yang dimiliki induk perusahaan sebagai sebuah perusahaan yang berbadan hukum.

Untuk memperjelas uraian di atas, berikut ini dijelaskan mengenai status hukum perseroan terbatas (baik pemegang sahamnya perorangan murni atau merupakan induk perusahaannya) dan konsekuensinya didalam hukum. Perseroan terbatas adalah badan hukum seperti yang ditentukan dalam pasal 1 angka 1 Undang-Undang Perseroan Terbatas No 40 Tahun 2007'2, karena diakui sebagai badan hukum maka Perseroan Terbatas juga diakui sebagi subyek hukum seperti halnya manusia.

Badan hukum adalah merupakan badan dimana oleh hukum disamakan dengan manusia alamiah. Karena disamakan dengan manusia alamiah maka badan hukum seperti halnya manusia dapat melakukan perbuatan hukum atas namanya sendiri, memiliki harta kekayaan

${ }^{12}$ Pasal 1 angka 1 Undang-Undang No 40 Tahun 2007 me nentukan bahwa Perseroan Terbatas, yang selanjutnya disebut perseroan, adalah badan hukum yang merupakan persekutuan modal,didirikan berdasarkan perjanjian, melakukan kegiatan usaha dengan modal dasar yang seluruhnya terbagi dalam saham dan memenuhi persyaratan yang ditetapkan dalam undang-undang ini serta peraturan pelaksanaannya. 
sendiri yang terpisah dari harta pribadi anggota-anggotanya dan memiliki tanggung jawab sendiri sebagai subyek hukum. Dengan demikian badan Hukum ini ada karena hukum, dan memang diperlukan keberadaannya sehingga disebut legal entity. Oleh karena itu maka disebut artificial person atau manusia buatan, atau person in law atau legal person /rechtpersoon.

Dengan status Perseroan Terbatas sebagai badan hukum, maka sejak saat itu hukum memperlakukan pemilik atau pemegang saham (entah pemegang sahamnya berupa orang atau badan usaha berbentuk PT) dan pengurus atau direksi, terpisah dari Perseroan Terbatas itu sendiri yang dikenal dengan istilah separate legal personality yaitu sebagai individu yang berdiri sendiri. Dengan demikian maka pemegang saham tidak mempunyai kepentingan dalam kekayaan Perseroan Terbatas, dengan demikian juga tidak bertanggung jawab atas utang-utang perusahaan atau Perseroan Terbatas. Maksudnya meskipun bila orang menjalankan perusahaan terus berganti, perusahaannya tetap memiliki identitas sendiri terlepas dari adanya penggantian para anggota pengurus ataupun pemegang sahamnya. Demikian pula kepentingan perusahaan tidak berhenti ataupun diulang kembali setiap terjadi pergantian manajer atau perubahan pemegang saham perusahaannya.

Sejalan dengan dengan uraian di atas bagi perseroan yang berbentuk badan hukum, maka secara hukum pada prinsipnya harta bendanya terpisah dari harta benda pemegang sahamnya (termasuk jika pemegang sahamnya merupakan induk perusahaan). Karena itu, tanggung jawab secara hukumjuga dipisahkan dari harta pribadipemilikperusahaanyang berbentukbadan hukum tersebut ${ }^{13}$. Sebagai contoh adalah apabila suatu PT melakukan suatu perbuatan dengan pihak lain, yang bertanggung jawab adalah PT tersebut sedangkan pemegang sahamnya bertanggung jawab hanya sebatas nilai nominal saham yang dimilikinya dalam PT tersebut tidak meliputi harta pribadinya yang lain.Hal ini sejalan dengan ketentuan yang terdapat pada pasal 3 ayat 1 UUPT yang menentukan bahwa Pemegangsaham (termasuk jika pemegang sahamnya berstatus sebagai induk perusahaan) Perseroan tidak bertanggung jawabsecara pribadi atas perikatan yang dibuatatasnamaPerseroandantidak bertanggungjawabataskerugianPerseroanmelebihi sahamyangdimiliki.Sehingga bisa disimpulkan bahwa karena dalam perusahaan kelompok/ group company masing-masing perusahaan (induk perusahaan dan anak-anak perusahaannya) yang tergabung dalam perusahaan kelompok itu merupakan subyek hukum-subyek hukum sendiri (karena masing-masing berbentuk perseroan terbatas) maka secara prinsip hukum (secara yuridis) masing-masing perusahaan tersebut tidak bertanggung jawab secara pribadi atas perikatan yang dilakukan masing masing perusahaan yang tergabung dalam perusahaan kelompok itu, demikian juga tidak bertanggung jawab atas kerugian masing-masing perusahaan melebihi saham yang dimilikinya.Dalam putusan MARI No.2810.K/Pdt/1989 pada perkara PT Ometraco Corporation, Tbk. melawan American Express Bank, Ltd. Singapore Branch, Oversea Chinese Banking Corporation Limited, Royal Bank Of Canada, etc memperkuat bentuk jamak secara yuridis dan kesatuan ekonomi pada perusahaan kelompok/perusahaan grup seperti uraian di atas. Dalam hal ini Mahkamah Agung memandang PT Ometraco Corporation dan anak perusahaan PT Ometraco Multi Artha sebagai subjek hukum mandiri, sehingga dalam pertimbangannya menyatakan bahwa memang dalam kegiatan bisnis masa kini maupun masa yang akan datang, berkembang bentuk perusahaan grup dengan sejumlah anak perusahaan.

Namun prinsip hukum tersebut diatas yang menyatakan bahwa pemegangsaham (termasuk jika pemegang sahamnya berstatus sebagai induk perusahaan) Perseroan tidak bertanggung jawabsecara pribadi atas perikatan yang dibuatatasnamaPerseroandantidak bertanggungjawabataskerugianPerseroanmelebihi sahamyangdimiliki, tidaklah bersifat mutlakdan diterapkan pada semua kasus hukum yeng berkaitan dengan perseroan tersebut.

${ }^{13}$ Munir Fuady, loc cit 
Artinya jika pemegang saham menyimpang dari ketentuan-ketentuan yang ditentukan dalam UUPT maka prinsip tersebut bisa tidak berlaku.

Ketidak mutlakan keberlakuan prinsip tersebut (dimana tadinya yang bertanggung jawab atas hutang-hutang perseroan adalah harus perseroan itu sendiri) secara normatif ditentukan dalam pasal 3 ayat 2 yang menentukan bahwa k etentuanpasal 3 ayat 1tidakberlakuapabila:

a) Persyaratan Perseroan sebagai badan hukum belum atau tidak terpenuhi;

b) Pemegang saham yang bersangkutan baik langsung maupun tidak langsung dengan itikad buruk memanfaatkan Perseroan untuk kepentingan pribadi;

c) Pemegang saham yang bersangkutan terlibat dalam perbuatan melawan hukum yang dilakukan oleh Perseroan; atau

d) pemegang saham yang bersangkutan baik langsung maupun tidak langsung secaramelawan hukum menggunakan kekayaan Perseroan, yang mengakibatkan kekayaan Perseroan menjadi tidak cukup untuk melunasi utang Perseroan.

Mengacu pada ketentuan pasal 3 ayat 1 dan ayat 2 UUPT tersebut bisa dijelaskan bahwa walaupun secara prinsip pemegang saham (termasuk pemegang sahamnya berstatus induk perusahaan) tidak bertanggung jawab atas hutang-hutang perseroan melebihi nilai nominal saham yang dimilikinya didalam perseroan tersebut namun jika hutang-hutang perseroan itu disebabkan terpenuhinya keadaan-keadaan yang ditentukan dalam pasal 3 ayat 2 maka pemegang saham bisa dimintakan tanggung jawabnya secara pribadi, tidak hanya sebatas nilai nominal saham yang dimilikinya di perseroan tersebut.

Ketentuan yang diatur dalam pasal 3 ayat 2 UUPT tersebut di atas dimana tanggung jawab hukum kepada pihak ketiga tidak hanya bisa dimintakan kepada perseroan saja tetapi juga pertanggung jawaban tersebut bisa dimintakan kepada pemegang saham dikenal dengan menembus selubung perusahaan berdasarkan penerapan teori piercing the corporate veil.

Untuk lebih memperdalam uraian di atas akan dikemukakan bahasan penerapan teori piercing the corporate veil dalam hubungan dengan holding company dan anak perusahaan, sebagai berikut ${ }^{14}$ :Teori piercing the corporate veil juga muncul dalam hal perusahaan dalam grup usaha. Dalam hal ini menurut ilmu hukum dikenal apa yang disebut dengan "Doktrin Instrumental" (Instrumentality Doctrine). Menurut doktrin tersebut, teori piercing the corporate veil dapat diterapkan. Dalam hal ini berarti yang bertanggung jawab bukan hanya badan hukum yang melakukan perbuatan hukum yang bersangkutan, melainkan pemegang saham (perusahaan holding) juga ikut bertanggung jawab secara hukum.

Masih dalam hubungan dengan grup perusahaan, penerapan teori piercing the corporate veil dapat dilakukan misalnya, daiam kasus-kasus sebagai berikut:

a. Adanya fakta-fakta yang menyesatkan,

Fakta yang menyesatkan itu adalah ketidaktegasan antara kegiatan yang dilakukan oleh induk perusahaan dengan kegiatan yang dilakukan oleh anak perusahaan. Contoh dari tindakan/fakta yang . menyesatkan tersebut adalah dalam hal adanya pencampuradukan antara usaha bisnis, pegawai atau aset dari perusahaan holding dengan anak perusahaan.

b. Terjadinya penipuan dan ketidakadilan,

Jika terjadipenipuanatauketidakadilanyang dilakukan oleh anakperusahaansehingga menguntungkan perusahaan holding, maka perusahaan holding juga dapat dimintakan tanggung iawabnya berdasarkan doktrin piercing the corporate veil tersebut.

${ }^{14}$ Ibid., hlm. 13-14 
c. Untuk melindungi pemegang saham minoritas,

d. Contoh tindakan yang merugikan pihak pemegang saham minoritas adalah jika teriadi transfer keuntungan yang diperoleh anak perusahaan kepada perusahaan holding atau kepada anak perusahaan lainnya.

Lebih lanjut, selain dari 3 (tiga) hal tersebut di atas, beberapa fakta di bawah ini dapat dicurigai sehingga dapat menyebabkan pemberlakuan teori piercing the corporate veil terhadap perusahaan holding atas perbuatan yang dilakukan oleh anak perusahaannya. Fakta-fakta tersebut adalah sebagai berikut ${ }^{15}$ :

a. Perusahaan holding dan anak perusahaan mempunyai pengurus, komisaris atau pegawai yang sama.

b. Anak perusahaan mempunyai modal yang sangat kecil.

c. Perusahaan holding membayar gaji, upah, kerugian dan ekspenses lainnya dari anak perusahaan.

d. Perusahaan holding memiliki seluruh atau hampir seluruh saham anak perusahaan.

e. Perusahaan holding membiayai anak perusahaan.

f. Anak perusahaan mempunyai bisnis hanya dengan perusahaan holding.

g. Anak perusahaan tidak mempunyai aset lain kecuali aset yang dialihkan dari perusahaan holding.

\section{KESIMPULAN}

Bahwa bentuk-bentukhubunganhukumantara Induk Perusahaan dengan anak perusahaandalamPerusahaanKelompokyang dapat menuju pada terjadinya hubunganhubungan konsern adalah dalam bentuk hubungan penggabungan/merger/fusi, pengambil alihan atau akuisisi, pendirian perusahaan anak/pemisahan dan joint venture. Bahwa dalam perusahaan kelompok/group company secara prinsip hukum (secara yuridis) induk perusahaan tidak bertanggung jawab secara pribadi atas perikatan yang dilakukan anak-anak perusahaannya, demikian juga tidak bertanggung jawab atas kerugian masing-masing perusahaan melebihi saham yang dimilikinya.Namun jika hutang-hutang anak-anak perusahaan itu disebabkan terpenuhinya keadaan-keadaan yang ditentukan dalam pasal 3 ayat 2 UUPT maka induk perusahaan bisa dimintakan tanggung jawabnya secara pribadi, tidak hanya sebatas nilai nominal saham yang dimilikinya pada anak perusahaan tersebut.

\section{DAFTAR PUSTAKA}

\section{Buku}

Sulistiowati.(2010). Aspek Hukum dan Realitas Bisnis Perusahaan Grup di Indonesia. Jakarta: Erlangga.

Raaijmakers.(1976). Joint venture. Kluwer Deventer.

Honee.(1981). Concernrecht en medezeggenschaps regelingen. Kluwer Deventer.

Raaymaker.(1976). Joint Venture. Kluwer Deventer.

Erman Rajagukguk, et al.(1995). Hukum Investasi. Jakarta: UI.

\footnotetext{
${ }^{15}$ Ibid., hlm. 16-17
}

292 Budi Sutrisno| Tanggung Jawab Yuridis Perusahaan.... 
Peter Mahmud dalam Salim HS, Budi Sutrisno.(2008). Hukum Investasi di Indonesia. Bandung: Rajawali Pers.

\section{Peraturan Perundangan}

Undang-undang No. 40 Tahun 2007 tentang Perseroan Terbatas. 